\title{
STRATEGI PENINGKATAN PENJUALAN KERIPIK BAWANG SAKINAH CIMAHI MELALUI PERLUASAN PASAR BAIK ONLINE MAUPUN OFFLINE DAN ANALISIS PENGGUNAAN SDM
}

\author{
Henny Utarsih \\ henny.utarsih@gmail.com \\ Heppy Vidyastuti \\ heppy.gofar@gmail.com \\ Wiendy Puspita Sari \\ wiendy.ps@gmail.com
}

SEKOLAH TINGGI ILMU EKONOMI EKUITAS

\begin{abstract}
ABSTRAK
UKM Keripik Sakinah merupakan sebuah industry rumahan keripik bawang yang bertempat di Kelurahan Utama, Kecamatan Cimahi Selatan, Kota Cimahi. Permasalahan utama yang dihadapi UKM ini adalah kurangnya alat untuk menambah kapasitas produksi, terbatasnya pemasaran keripik sakinah, dan belum teraturnya pengelolaan SDM. Solusi yang diberikan dalam Pengabdian Kepada Masyarakat ini adalah pemberian mesin pengulen adonan kapasista $2.5 \mathrm{~kg}$, pelatihan e-marketing dan pembuatan laporan analisis penggunaan SDM (merancang Job Analysis, Pembuatan Struktur, dan sistem penggajian). Dengan adanya pelatihan dan pendampingan pada UKM Keripik sakinah mengalami peningkatan omzet penjualan karena meningkatnya kapasitas produksi; adanya ekpansi pasar melalui bertambahnya pasar baru baik pasar offline dengan mengikutkan menjadi peserta pada Masyarakat Marketing Indonesia dan pembuatan online marketing dengan adanya Facebook dan Instagram Sakinah di Media Sosial dan pendaftaran UKM Sakinah pada aplikasi go-food pada go-jek; serta SDM keripik sakinah lebih teratur dan terarah dalam bekerja.
\end{abstract}

Kata kunci: Penjulan, Perluasan Pasar, Penggunaan SDM.

\section{PENDAHULUAN}

\subsection{Analisis Situasi}

UMKM Sakinah berada di Kelurahan Utama Kecamatan Cimahi Selatan Kota Cimahi. Pemilik Keripik Bawang Sakinah memulai usahanya pada tahun 2013, berawal dari keinginan pemilik untuk membantu menambah penghasilan keluarga karena bertambahnya pengeluaran dan adanya aktivitas tambahan selain mengurus rumah tangga. Pada saat itu Pemerintah Kota Cimahi mrngadakan pelatihan pembuatan keripik bagi ibu-ibu PKK di daerah Cimahi. Nama Sakinah diambil dari nama kelompok PKK saat pekatihan tersebut. Produk awal pertama dibuat adalah Cheese Stik, namun produk ini sudah banyak dipasaran dan mudah rusak karena rapuh, akhirnya pemilik melakukan pencarian ide dengan melakukan googling di internet dan mendapatkan ide untuk 
membuat keripik bawang karena resepnya yang mudah dilakukan. Pemilik melakukan uji coba pasar dengan memberikan tester secara cuma- Cuma kepada masyarakat sekitar rumahnya. Respon yang yang didapat cukup positif, yaitu Keripik Bawang Sakinah memiliki rasa yang enak dan gurih. Akhirnya pemilik memberanikan diri untuk memasarkan Keripik Bawang Sakinah ke warung-warung di dekat rumahnya, kemudian mencoba memperluas pasar dengan melakukan konsinyasi.

Konsinyasi yang saat ini sudah dilakukan dengan Toko Kue Cipta Rasa Kerkof Cimahi, Toko kue Cipta Rasa Cihanjuang Cimahi, Toko kue Cipta Rasa Geger Kalong Bandung, Toko Kue Val's Bandung, Toko Kue Peuyeum ketan Istimewa Cimahi, T-Mart Universitas Telkom Bandung, Kantin Rumah Sakit Gigi dan Mulut Cimahi , Toko Buana Cimahi, Kantin BPJS Cimahi, Kantin AWC Cimahi, Kantin SMA Negeri 16 Bandung, Toko Kabita Pasteur Bandung, Toko Rizki Snack Pasteur Bandung, Rumah Makan Punclut Bandung, Rumah Kana Bandung. Untuk memenuhi permintaan pasar, pemilik mendapatkan kendala berupa kegagalan poduk. Kegagalan produk dipicu oleh kondisi adonan tidak terstandarisasi, berbeda orang yang menguleni adonan, berbeda pula ketebalan adonan akhir. Selain itu kegagalan produk juga dipicu oleh panas yang tidak stabli saat proses penggorengan.

Kondisi bauran pemasaran Keripik Bawang Sakinah saat ini adalah sebagai berikut :

a. Produk memiliki beberapa kelebihan diantaranya, lebih tahan lama karena kandungan minyak sudah dibuat seminimal mungkin dengan adanya penggunaan spinner, sehingga produk yang dihasilkan gurih dan renyah. Rasa yang ditawarkan bervariasi, yaitu rasa original (bawang), kencur, cabe rawit, dan balado. Ukuran Keripik Bawang Sakinah disesuaikan dengan daya beli konsumen yang bervariasi. Keripik Bawang Sakinah dikemas dalam berbagai ukuran, yaitu kemasan 150 gr, 250 gr, 500 gr,

b. Harga Keripik Bawang Sakinah cukup terjangkau, sheingga dapat dinikmati berbagai kalangan. Harga jual untuk reseller adalah $\mathrm{Rp} 60.000 / \mathrm{kg}$.

c. Tempat Pemasaran Keripik Bawang Sakinah adalah toko oleh-oleh, minimarket, koperasi, dengan sistem konsinyasi. Saat ini Keripik Bawang Sakinah dapat dibeli di Toko Kue Cipta Rasa Kerkof Cimahi, Toko kue Cipta Rasa Cihanjuang Cimahi, Toko kue Cipta Rasa Geger Kalong Bandung, Toko Kue Val's Bandung, Toko Kue Peuyeum ketan Istimewa Cimahi, TMart Universitas Telkom Bandung, Kantin Rumah Sakit Gigi dan Mulut Cimahi , Toko Buana Cimahi, Kantin BPJS Cimahi, Kantin AWC Cimahi, Kantin SMA Negeri 16 Bandung, Toko Kabita Pasteur Bandung, Toko Rizki Snack Pasteur Bandung, Rumah Makan Punclut Bandung, Rumah Kana Bandung.

d. Promosi yang dilakukan selama ini, yaitu menawarkan kepada setiap pedagang tentang produk ini, teman dekat dan lingkungan sekitar dengan kata lain promosi mulut ke mulut. Peluang pasar untuk produk keripik bawang ini sangat besar melihat pertumbuhan kota Cimahi dan peluang pasar yang menjanjikan dengan dekatnya jarak Cimahi dan kota Bandung yang terkenal dengan salah satu pusat wisata kuliner.

Analisis terkait kondisi dan potensi wilayah dari segi fisik, ekonomi, dan sosial maupun lingkungan yang relevan dengan kegiatan yang akan dilakukan adalah sebagai berikut :

1. Segi Fisik

Usaha Keripik Bawang Sakinah terletak di Kelurahan Utama Kecamatan Cimahi Selatan. Akses menuju lokasi ini dapat dijangkau baik dengan kendaraan roda dua, maupun dengan kendaraan roda empat. Namun untuk kendaraan roda empat, tidak dapat langsung masuk ke lokasi usaha 
keripik. Usaha ini merupakan usaha rumahan, sehingga tempat produksi masih bergabung dengan rumah tinggal.

Sarana dan prasarana yang dimiliki oleh usaha Keripik Bawang Sakinah antara lain sebagai berikut:
a. Timbangan kecil
b. Tempat makan plastik besar
c. Penggorengan
d. Spatula
e. Tampah
f. Kompor
g. Sealer
h. Etalase

\section{Segi Sosial}

Masyarakat sekitar wilayah Utama kecamatan Cimahi Selatan pada umumnya relatif sudah mengenal usaha Keripik Bawang Sakinah, sehingga tidak perlu lagi mencari atau bertanya untuk sampai di lokasi produksi atau usaha. Masyarakat Bandung merasa kesulitan untuk membeli Keripik Bawang Sakinah karena belum adanya pemasaran secara online dan sulitnya pembelian Keripik Bawang Sakinah dengan Go-Jek. Tidak adanya identitas plang nama dan lokasi produksi yang kurang strategis menjadi penyebab utama belum terkenalnya usaha Keripik Bawang Sakinah secara luas.

\section{Segi Ekonomi}

Keripik bawang Sakinah merupakan usaha rumahan, sehingga secara ekonomi sisi permodalan terutama ekonomi, masih tergantung pada dan bersumber dari pendapatan rumah tangga, sehingga belum terpisahkan secara profesional.

\subsection{Identifikasi Masalah}

Masalah utama yang dialami oleh usaha keripik Sakinah sebagai berikut:

1. Peralatan yang digunakan untuk produksi masih skala untuk penggunaan kegiatan memasak sehari- hari misalnya penggorengan kecil, menguleni adonan masih manual memakai tangan, alat cetak keripik bukan untuk skala produksi berupa pisau bergerigi sehingga hasil yang didapatkan berbeda-beda kebesaran dan ketebalan keripik. Kebutuhan mesin uleni (mixer skala produksi), penggorengan yang besar, mesin pencetak lempengan keripik dan mesin timbangan dibutuhkan terutama untuk memenuhi permintaan keripik bawang yang semakin meningkat dengan pasokan yang cukup besar

2. Pemasaran masih berupa menitipkan keripik bawang pada toko-toko dengan cara konsinyasi belum adanya ekspansi pasar yang lebih besar dan pemasaran secara online. Electronic word of mouth (EWOM) merupakan metode marketing yang sedang berkembang dan biasanya menggunakan social media, karena lebih efektif dalam menjaring pelanggan (Spotler et al, 2014). Saat ini mitra akan ditawarkan pembentukan pasar baru dengan memperkenalkan pada komunitas Masyarakat Marketing Indonesia dan pembuatan akun di Facebook dan Instagram serta pendaftaran aplikasi go-food pada Gojek. Dengan ini diharapkan omzt penjualan Keripik Bawang Sakinah dapat meningkatkan.

3. Penggunaan tenaga kerja masih mengandalkan anggota keluarga sehingga perlu dilakukan analisis jabatan, pembentukan struktur organisasi dan sistem penggajian. Pembagian kerja yang tepat dapat meningkatkan efisiensi dalam bekerja (Dessler, 2015). Dengan ini pemilik dapat membandingkan keuntungan dan kerugian jika merekrut tenaga dari luar dengan maupun dari keluarga sendiri.

4. Pembenahan pemasaran dengan pemasangan plang nama untuk promosi. Promosi adalah salah satu aspek dari Marketing Mix yang berdampak signifikan dalam penjualan (Kottler \& Keller, 2016). Saat ini mitra tidak memiliki identitas atau plang nama di lokasi produksi.

5. Perizinan halal yang sudah expire. Saat ini mitra sudah memiliki izin halal dari 
MUI namun masa berlakunya sudah kadaluarsa.

6. Belum pahamnya terkait penyusunan laporan keuangan dan perhitungan harga pokok penjualan. Saat ini mitra belum menyusun laporan keuangannya dan belum paham dalam menghitung laba kotor

\section{METODE KEGIATAN}

\subsection{Solusi Yang Ditawarkan}

Berdasarkan permasalahan yang dihadapi oleh mitra seperti tertulis dalam bab sebelumnya, beberapa alternatif solusi yang dapat ditawarkan adalah pemberikan pelatihan perluasan pasar dengan emarketing dan penggunaan SDM, serta bantuan berupa mesin adon.

2.2 Mekanisme Pelaksanaan

Rancangan mekanisme pelaksanaan kegiatan program ini dilakukan dengan mengadopsi langkah-langkah action research yang terdiri dari tiga tahapan, yaitu: perencanaan, pelaksanaan, dan tahap akhir (Henny et al, 2016). Kegiatan-kegiatan atau aktivitas-aktivitas dari masing-masing tahapan adalah sebagai berikut:

\section{a. Perencanaan}

Melakukan pertemuan dengan pihak UMKM Keripik Bawang Sakinah yaitu Ibu Nuriah, mengenai visi misi tim STIE Ekuitas dalam rangka Tri Dharma perguruan tinggi dimana salah satunya adalah pengabdian pada masyarakat, dan tim menjelaskan akan adanya bantuan dari STIE Ekuitas pada UMKM binaan

b. Pelaksanaan

Untuk mengatasi masalah produksi, tim pengabdian memberikan alat bantu produksi berupa mesin ulen adonan dengan kapasitas $5 \mathrm{~kg}$. Untuk mengatasi masalah perluasan pasar, tim pengabdian memandu pemilik usaha untuk membuat akun di media social, yaitu di facebook, instagram, dan membantu menjadi rekanan go-jek. Tim pengabdian juga memberikan modul e-marketing dan penggunaan SDM agar pemilik usaha dapat mengoptimalkan pemasaran dan alokasi SDM. c. Tahap Akhir

Tahap akhir merupakan monitoring dan evaluasi. Tim pengabdian melakukan pendampingan dan memantau hasil penjualan sebagai bentuk evaluasi dari pemberian bantuan yang telah dilaksanakan.

\section{HASIL dan LUARAN}

\subsection{Hasil Kegiatan}

Target pengabdian kepada masyarakat adalah UMKM Keripik Sakinah di kelurahan Cisarante

1. Mitra memiliki mesin pengulen adonan dalam skala besar

2. Pembuatan e-marketing melalui pembuatan e-mail, Facebook, Instagram, atas nama Keripik Bawang Sakinah dan pendaftaran go-food pada Gojek

3. Terbentuknya pasar baru dari Offline marketing dengan menjadi komunitas Masyarakat Marketing Indonesia

4. Terbentuknya stuktur orgaisasi, analisis jabatan, dan sistem penggajian.

\subsection{Luaran}

Jenis luaran yang akan dihasilkan dari kegiatan pengabdian masyarakat adalah;

1. Jasa, berupa bertambahnya keterampilan baru mengenai cara menggunakan Online Marketing dan terdaftar anggota komunitas baru Masyarakat Marketing Indonesia untuk memperluas pangsa pasar keripik Sakinah. Terdaftar menjadi member gofood dari aplikasi Go-jek, bertambahnya pengetahuan mengenai cara mengelola SDM melalui struktur organisasi, analisis jabatan, dan sistem penggajian. Pendampingan selama setahun untuk memantau peningkatan omzet penjualan.

2. Produk, berupa:

- Manual book atau modul untuk analisis pengelolaan SDM untuk membuat struktur organisasi, analisis jabatan, dan sistem penggajian. 
- Manual book atau modul untuk pembuatan e-marketing, untuk memasarkan dan melakukan promosi melalui internet, dan pendaftaran aplikasi go-food di Gojek.

- Pembelian alat produksi seperti mesin pengulen adonan besar.

\section{KESIMPULAN}

UKM Keripik Bawang Sakinah merupakan industry rumahan keripik bawang yang bertempat di Kota Cimahi, tepatnya di Kelurahan Utama Kecamatan Cimahi Selatan. Dalam produksi, pemilik Keripik Bawang Sakinah mengandalkan bantuan tenaga dari keluarga, sehingga kapasitas produksi tidak stabil, tergantung dari ketersediaan waktu dari tenaga keluarga yang membantu. Alat yang digunakan pun terbatas, sehingga kapasitas produksi sedikit.

Dari segi pemasaran, Keripik bawang Sakinah menggunakan sistem konsinyasi dengan warung di sekitar rumah dan kantin universitas tempat suami pemilik bekerja. Sedikitnya jalur distribusi ini menyebabkan tingkat penjualan Keripik Bawang Sakinah tak kunjung naik.

Pengelolaan SDM keripik sakinah pun belum teratur. Belum ada pembagian kerja dan penggajian yang jelas, sehingga mengganggu kapasistas produksi dan penentuan Harga Pokok Penjualan.

PKM ini bermaksud membantu penyelesaian masalah UKM Keripik Sakinah dengan memberikan alat pengulen adonan, pelatihan e-marketting untuk memperluas pasar, serta pembuatan job analysis, struktur, \& sistem penggajian untuk memperbaiki pengelolaan SDM.

Luaran dari PKM terhadap UKM Keripik Sakinah adalah modul e-marketing, modul pengelolaan SDM. Dengan Modul emarketing, Keripik Sakinah berhasil membuat jalur pemasaran melalui social media berupa Instagram dan Facebook. Dengan modul pengeloaan SDM, Keripik Sakinah berhasil membuat job analysis, struktur dan sistem penggajian. Selain itu alat pengulen adonan yang diberikan membuat pemilik keripik sakinah tidak tergantung pada keluarganya dalam hal produksi.

Dengan adanya PKM yang dilaksanakan di UKM Keripik Sakinah, Keripik Sakinah dapat meningkatkan kapasitas produksinya, melebarkan pemasarannya, dan mengelola SDM-nya dengan lebih baik.

\section{DAFTAR PUSTAKA}

Dessler, Gary. 2015. Manajemen sumber Daya Manusia. Edisi 14. Salemba Empat. Jakarta

Henny Utarsih, Heppy Agustiana, Efi Fitriani. 2016. Modul Pembuatan berbagai jenis barang fungsional yang cantik, menarik,unik eksklusif dari bahan dasar sampah plastik dan pelathan e-marketing. Bandung

Kotler, Philip and Kevin Lane Keller (2016): Marketing Management, 15th, Edition New Jersey: Pearson Pretice Hall, Inc.

Spolter, S.W., Sussan, F., Gould, S. 2014. An integrative approach to eWOMand marketing communications. Corporate Communications: AnInternational JournalVol. 19 No. 3, 2014pp. 260-274. 